\title{
Research on Ranking Algorithm of Domestic Scientific Research Institutions Based on Research Gate RG Score Index
}

\author{
Jian Zhou ${ }^{1, \text { a }}$, Ning Cai ${ }^{1, b^{*}}$ and Xiaokun Liu $^{2, c}$ \\ ${ }^{1}$ College of Electrical Engineering, Northwest University for Nationalities, China \\ ${ }^{2}$ School of Foreign Language, Northwest University for Nationalities, China \\ azhoujianfrank@126.com, bcaining91@tsinghua.org.cn, 'Ixk0523@163.com
}

*The corresponding author

Keywords: University ranking; Research gate; RG Score index; New index

\begin{abstract}
University ranking is an important part of educational evaluation. It can enhance the visibility and reputation of a school, dynamically reflect the development regulation of higher education and attract the public and social organizations to pay close attention to higher education. For this, almost all major colleges and universities attach great importance to the effect and influence of the university evaluation and ranking, all these issues have become the focus of the question and the university ranking is full of controversy, so it has become one of the focus in the current social problems. This paper is mainly study the research gate website and some algorithm of its RG score index, and by studying and comparing the ranking status of 120 Universities and its corresponding RG score index which is launched by the alumni association. This paper presents new index and some reliable data to statistic and analysis the ranking of universities, and it is concluded that the research gate RG score, the total membership and the impact factor can be approved as the evaluation index of university ranking algorithm.
\end{abstract}

\section{Introduction}

In recent years, Scientometrics development in our country is entering a new era [1]. One of the leading international scientific measuring field and China's scientific metrology research is quite level. If you support more in this area, it should be able to get faster development [2]. Scientometrics from belongs to the level 1 discipline of computer science and technology. It is the study of the science and technology innovation measurement and analysis, the main research topics include impact factor, citations of measurement [3,4], using the data research the impact of journals and research institutes. So the research on university ranking is an important application of scientometrics. University ranking is evaluation of university education and scientific research is an effective way, it represents a degree at the university of school quality and level of education, can the university directly presented to the social level and status. In this background, the influence of university ranking is also very broad sweep [5]. With the vigorous development of China's higher education, the sharp increase in the number of colleges and universities and the imbalance between educational quality, makes the college education is faced with great challenge. The evaluation and focus on increasing the quality of university. Under this background, the variety of forms, the emphasis is not the same way of all kinds of university ranking has been, received extensive attention of China's higher education and the social from all walks of life. University rankings in China in 1987.

At present, our country's higher education is in a stage of vigorous development, faced with a variety of opportunities and challenges [6]. Reasonable and fair assessment in colleges and universities is an important factor of progress and development of colleges and universities. Since the end of 2000, set out to research institutions and institutions of higher learning evaluation and assessment of the academic degree evaluation. Scientific research institutions of our country by the evaluation results of various disciplines of the overall level of ranking. Relevant experts agree that subject evaluation can reflect the same subject research achievement gap between different schools, this greatly enhance the strength of colleges and universities to strengthen the academic and 
education faith and courage. Evaluation experts and evaluation object, evaluation index and evaluation method carried on the thorough discussion, on this basis to determine the most scientific assessment of the plan [8]. After each end of the evaluation work, through each aspect expert advice, the index system, evaluation technology and so on carries on the revision and consummation. Carefully take Suggestions from all walks of life and evaluation methods for the continuous improvement in order to make evaluation results more reasonable and fair.

\section{Problem Formulation and Preliminaries}

The purpose of any university rankings are not. While university ranking will do is to research the service object and service methods [9]. Existing university rankings, whether it is for the students to accept a certain level of education services, or for the society better service evaluating the academic status of university, or out to improve the academic views of the a research service, the purpose is very clear [10]. So this article embarks from the theoretical Research, in order to Research the Gate index as the index ranking, and put forward the use of computer programming software. We presents a ne approach as follows:

(1) Put forward a new index to the university ranking.

(2) Get a new simple algorithm, makes scientific research institution rankings work more simple and efficient.

(3) Use computer technology ranked software programming is put forward, make university rankings and dynamic update automatically.

(4) Vigorously promote the discipline construction, enhance the international competitiveness of China's higher education and degree.

(5) Through the communication with different levels of the university of world and competition to stimulate the vitality of academic research, and clearly the same subject position in the international and domestic, get the development direction and development goals.

(6) Meet the demand of social talent in all walks of life to provide students study information and a way out.

Scientists are Research evaluation Gate website, all the best person for academic Research, and they will pass their own all of the published or unpublished papers won the reputation of the corresponding values. Based on this consideration, the RG Score algorithm focuses on Research scientists Research and published to the contribution of Gate whether be peer recognition. Also it is because the RG Score is based on the peer view of your research work, so nobody can directly affect the RG Score. The same principle applies to the contribution of low quality. The contribution of low quality will not attract positive feedback and recognition from site. This means that the low quality of paper and contribution will not affect the RG Score. Although the RG Score measure is the personal reputation, but in general, a group of colleagues' research results can reflect the level of a scientific research institution. Research on the Gate of the scientific Research units home page with RG Score for the world Research institutions provide a view and basis.

Table 1 Research Gate Website Each Index

\begin{tabular}{|c|c|c|c|c|c|}
\hline Name & $\begin{array}{c}\text { Total RG } \\
\text { Score }\end{array}$ & $\begin{array}{c}\text { Total Number } \\
\text { of Members }\end{array}$ & $\begin{array}{c}\text { Total Impact } \\
\text { Factor }\end{array}$ & $\begin{array}{c}\text { Impact Factor } \\
\text { of Per Capita }\end{array}$ & $\begin{array}{c}\text { RG Score of } \\
\text { Per capita }\end{array}$ \\
\hline Proportion & $12 \%$ & $14 \%$ & $33 \%$ & $11 \%$ & $30 \%$ \\
\hline
\end{tabular}

First two columns in Table 2 are Chinese alumni network part of the university ranking in China in 2016, this paper selected the top 5 and ranked in 5 after another 20 representative universities. In addition this paper Research Gate website by artificial collected in the table of 5 universities always RG Score, total impact factor, and the total number of members, and calculate the per capita 5 universities RG Score and per capita impact factor, separately listed in the table.

Can be seen from the diagram in this paper, the study of 5 universities in China alumni association ranks in order to make the RG Score index discount figure with general Chinese alumni 
network university rankings in 2016 the same trend, that is the total of the 10 universities RG Score, the total number of members and the general impact factors as rankings are falling back, but there is no lack of among them some university is not in accordance with this trend. Renmin university of China, for example, in 2016 China alumni association website ranking in the sixth place, but it is in the Research of total Gate RG Score, the total number of members and the general impact factors were lower than ranking followed by Shanghai jiao tong university, etc. This is because the subject is given priority to with liberal arts, renmin university of China, it does very little international communication, so the Research Gate website published academic papers is also less, this led to its impact factor and the RG Score is very low.

Table 2 The Indicators in University Research Gate

\begin{tabular}{|c|c|c|c|c|c|c|}
\hline Rank & $\begin{array}{c}\text { The Name } \\
\text { of } \\
\text { University }\end{array}$ & $\begin{array}{c}\text { The total } \\
\text { RG Score }\end{array}$ & Members & $\begin{array}{c}\text { The Total of } \\
\text { Impact } \\
\text { Factor }\end{array}$ & $\begin{array}{c}\text { Impact } \\
\text { Factor of } \\
\text { Per Capita }\end{array}$ & $\begin{array}{c}\text { RG Score } \\
\text { of Per } \\
\text { capita }\end{array}$ \\
\hline 1 & $\begin{array}{c}\text { Bei jin } \\
\text { University }\end{array}$ & 43291.6 & 7696 & 72441.06 & 5.63 & 9.41 \\
\hline 2 & $\begin{array}{c}\text { Tsinghua } \\
\text { University }\end{array}$ & 59106.81 & 9994 & 58907.37 & 5.91 & 5.89 \\
\hline 3 & $\begin{array}{c}\text { Fudan } \\
\text { university }\end{array}$ & 43727.65 & 6405 & 69476.72 & 6.83 & 10.85 \\
\hline 5 & $\begin{array}{c}\text { Wuhan } \\
\text { University }\end{array}$ & 26041.95 & 5715 & 30876.78 & 4.56 & 5.40 \\
\hline $\begin{array}{c}\text { Zhejiang } \\
\text { University }\end{array}$ & 47764.01 & 7962 & 75216.27 & 6.00 & 9.45 \\
\hline
\end{tabular}

Table 2 illustrates the RG Score per capita and per capita impact factor is not suitable for as indicators of university ranking. Therefore, the following will be summarized with Research the total Gate website RG Score, total impact factor and total membership evaluation index of university as follows:

$$
\nabla=\alpha x+\beta y+\gamma z
$$

Impact factor calculation formula as follows:

$$
\operatorname{IF}(k)=\left(n_{k}-1+n_{k}-2\right) /\left(N_{k}-1+N_{k}-2\right)
$$

The calculation of tertiary evaluation index score as follows:

$$
\text { Average }=100 \cdot \sum(\alpha \cdot \beta) / \operatorname{Max}\left(\sum \beta \cdot \gamma\right)
$$

\section{Conclusion}

Through to the China alumni association website ranking index system and Research the Gate of the comparison of the site each index ranking, we can be more objective, comprehensive understanding to the various advantages and disadvantages of college ranking system. Chinese alumni network in China is more authoritative university rankings, from its international influence, in the perspective of the national development and social contribution and evaluate the Chinese university, Chinese university of world civilization, the country prosperous and social progress 
contribution and influence, its advantage is very clear. Our society for a university appraises the system, not only for it to be authoritative, be it uphold justice for the immediate interests of the social from all walks of life to bring the corresponding value. University ranking system in our country there are still many deficiencies but has been in constant progress and perfect. Develop and perfect the evaluation system of the authority of a reliable, very beneficial to promote our country and the world of the higher education level. Therefore, we must first do reasonable distribution of all existing samples, reduce the irrational competition between universities, to the formation and development, distinctive style diversified school-running mode. Second, we must pay attention to each single index evaluation of universities, as discussed in this paper the RG Score per capita and per capita impact factor, etc., can be more comprehensive rationally to the audience Show the universities teaching quality and scientific research. Finally, in the hope that through a variety of different rank evaluation system, we can offer a force for education career.

\section{References}

[1] Leydesdorff, L. and Milojevic, S., "Scientometrics" arXiv: 1208. 4566 (2013), forthcoming in.

[2] De Solla Price, D., editorial statement. Scientometrics Volume 1, Issue 1 (1978).

[3] Nian Cai Liu, Ying Cheng, Li Liu. Academic ranking of world universities using scientometrics - A comment to the "Fatal Attraction" [J]. Scientometrics. 2005 (1).

[4] Anthony F.J.van Raan. Fatal attraction: Conceptual and methodological problems in the ranking of universities by bibliometric methods [J]. Scientometrics. 2005 (1).

[5] Francesca De Battisti, Giovanna Nicolini, Silvia Salini. Occupational Outcomes according to University Ranking [J]. Journal of Applied Sciences, 2011, 11(4).

[6] William Yat Wai Lo. University rankings as a zoning technology: a Taiwanese perspective on an imaginary Greater China higher education region [J]. Globalisation, Societies and Education, 2013, 11(4).

[7] Matthews, David. "Do academic social networks share academics' interests?". Times Higher Education. Retrieved 22 April 2016.

[8] Isidro F. Aguillo, Judit Bar-Ilan, Mark Levene, José Luis Ortega. Comparing university rankings [J]. Scientometrics, 2010, 85 (1).

[9] Sarah S. Amsler, Chris Bolsmann. University ranking as social exclusion [J]. British Journal of Sociology of Education, 2012, 33(2).

[10]Jin B H. The AR-index: Complementing the h-index. ISSI Newsletter, 2007, 3(1). 